\title{
8 pommbalina \\ Quando o doce é corpo: antropomorfismo e antroponímia na doçaria tradicional portuguesa
}

\author{
Autor(es): $\quad$ Dias, Paula Barata \\ Publicado por: Imprensa da Universidade de Coimbra \\ URL \\ persistente: URI:http://hdl.handle.net/10316.2/45239 \\ DOI: $\quad$ DOI:https://doi.org/10.14195/978-989-26-1721-3_12 \\ Accessed : $\quad$ 26-Apr-2023 12:47:11
}

A navegação consulta e descarregamento dos títulos inseridos nas Bibliotecas Digitais UC Digitalis, UC Pombalina e UC Impactum, pressupõem a aceitação plena e sem reservas dos Termos e Condições de Uso destas Bibliotecas Digitais, disponíveis em https://digitalis.uc.pt/pt-pt/termos.

Conforme exposto nos referidos Termos e Condições de Uso, o descarregamento de títulos de acesso restrito requer uma licença válida de autorização devendo o utilizador aceder ao(s) documento(s) a partir de um endereço de IP da instituição detentora da supramencionada licença.

Ao utilizador é apenas permitido o descarregamento para uso pessoal, pelo que o emprego do(s) título(s) descarregado(s) para outro fim, designadamente comercial, carece de autorização do respetivo autor ou editor da obra.

Na medida em que todas as obras da UC Digitalis se encontram protegidas pelo Código do Direito de Autor e Direitos Conexos e demais legislação aplicável, toda a cópia, parcial ou total, deste documento, nos casos em que é legalmente admitida, deverá conter ou fazer-se acompanhar por este aviso.

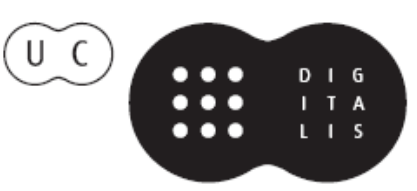


Carmen Soares

Gilene da Silva Gomes Ribeiro

(coords.)

\section{Mesas \\ LUSO-BRASILEIRAS}

\section{ALIMENTAÇÃO, SAÚdE \& GULTURA}

\section{VOLUME I}

IMPRENSA DA UNIVERSIDADE DE COIMBRA COIMBRA UNIVERSITY PRESS

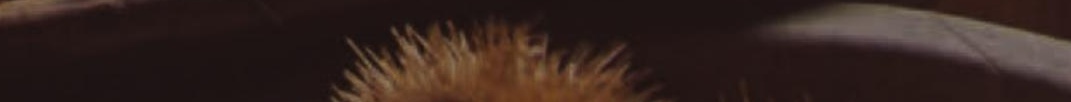




\title{
QUANDO O DOCE É CORPO. Antropomorfismo e Antroponímia na DOÇARIA TRADICIONAL PORTUGUESA
}

\section{(When the sweet is body. Anthropomorphism and Antropony in traditional Portuguese confectionery)}

\author{
Paula Barata Dias \\ Universidade de Coimbra \\ Centro de Estudos Clássicos e Humanísticos da Universidade de Coimbra \\ (pabadias@hotmail.com)
}

Resumo: A doçaria tradicional portuguesa chegou até nós enquanto património gastronómico distinto, através de um percurso histórico na época moderna e contemporânea que a singularizou nos seus traços. $\mathrm{O}$ acesso mais fácil ao açúcar, as celebrações e festividades populares religiosas que proporcionavam a fartura ou a diversidade alimentar e o ambiente monástico em que a doçaria conventual era trabalhada convergiram para o desenvolvimento de produtos alimentares diversos, destinados ao prazer gustativo. Nesta participação, pretendemos explorar os códigos verbais e morfológicos presentes na doçaria tradicional, conventual e popular, enquanto expressão significativa de uma linguagem espiritual e de uma religiosidade inerentes. PAlaVRas-Chave: açúcar, antropomorfia, antroponímia, doçaria popular, doçaria conventual, espiritualidade, religião.

Авstract: The traditional Portuguese sweets came to us as a distinctive gastronomic heritage through a historical journey in the modern and contemporary times that singled it out in its features. Easier access to sugar, celebrations and popular religious festivities that provided abundance or food diversity, the monastic environment in which monastic sweets were worked, converged on the development of various food products for taste. In this participation, we intend to explore the verbal and morphological codes present in traditional, monastic and popular sweets as a significant expression of an inherent spiritual language and religiosity.

KEYwORDs: sugar, anthropomorphism, anthroponomy, popular pastry, monastic pastry, spirituality, religion. 


\section{i. Introdução: o Barroco enquanto estética dominante na ARTE DA DOÇARIA CONVENTUAL}

A motivação para este artigo partiu de uma observação que partilhamos durante uma ocasião em que viajávamos com a família. Observando os detalhes de alguns altares de igrejas integradas em mosteiros situados no centro e no norte de Portugal (por exemplo, o retábulo-mor da Igreja do mosteiro de Santa Mafalda, em Arouca, fundação cisterciense; os altares das capelas do mosteiro das Chagas de Lamego, integrados no Museu da mesma cidade, fundação franciscana; o retábulo-mor da igreja do Desterro, em Lamego; ainda o altar lateral do Mosteiro de Tibães que alberga o conjunto escultórico da "Visão de Santa Lutegarda"). "-Tantos anjos de ouro! Mais de cem”, "- Acho que são mais de mil”, comentavam os meus companheiros de viagem, entretendo-se a identificar, na profusão da talha dourada do barroco português, as variadas esculturas dos anjos dourados, os putti de origem italiana, figurações de crianças despidas, gordinhas, sorridentes e com ar feliz que nós apelidamos jocosamente como "anjinhos papudos". A imagem desses anjos de ouro aproximou-se, na minha memória, do termo "papos de anjo”, reservado para um doce particular da doçaria conventual.

Numa observação primária e ingénua, notamos uma coerência visual e estética que acompanha a identificação linguística entre "papos de anjo" e "anjinhos papudos", sejam estes os putti da escultura italiana, sejam as crianças de tenra idade fofinhas e sorridentes que se cruzam connosco: o mesmo dourado do ovo, do ouro e dos cabelos louros, as formas redondas, sem ângulos ou arestas, a pequenez que concentra uma beleza pacífica. A par dessa observação superficial que resulta de um contágio visual, repare-se que o momento histórico do séc. XVII e XVIII que vê emergir o estilo e a decoração barrocas na arquitetura religiosa é também a altura das origens históricas e sociológicas dos doces conventuais como produtos de um saber-fazer nos mosteiros portugueses, sobretudo os femininos.

Nos finais do séc. XVI, as tendências artísticas europeias evoluem para apreciar os volumes, as formas e as linhas curvas, em detrimento da austeridade clássica dos ângulos limpos, para surpreender o recetor com a imaginação infinita dos sentidos visuais e das cores, o gosto pelo irregular, o extravagante, o emotivo e o excessivo ${ }^{1}$. Em Portugal, a estética barroca acompanhou os anos de ouro proporcionados pelas riquezas do Brasil, dando origem a um programa arquitetónico, mas sobretudo decorativo, que prolifera na talha dourada e nos azulejos da arte sacra portuguesa, com a edificação ou a recu-

1 A bibliografia sobre o movimento artístico e literário Barroco e sobre a categoria estética do Barroco é muito abundante. Salientamos d'Ors 1935 ed. 2002. Maravall 1975 ed. 1998. Camino, 2002. Hills ed. 2011. 
peração de fundações monásticas antigas associadas à renovada espiritualidade estimulada pela contrarreforma. Paulino Mota Soares, no livro Mesa, doces e amores no séc. XVII português, publicado em 1999, identificou com grande agudeza esse momento histórico da convivência entre o movimento artístico e estético barroco na língua, na arquitetura e na sociedade e a realidade da emergência da doçaria conventual associada à prosperidade dessas casas monásticas, repletas de "centenas e centenas de jovens mulheres, frescas e solitárias noviças mais aptas para o amor do que para a mística e o saltério". Eram essas as "criadoras dos pontos de açúcar, de uma cozinha e de uma doçaria tão excelente e excitante [...]”. Também Dina Sousa se pronunciou sobre esse singular momento da história portuguesa, proporcionado pela disponibilidade dos recursos - o açúcar, cuja produção, primeiro na Madeira e depois no Brasil, permite fornecer abundante e mais acessível matéria-prima que, até então, só chegava aos mais abastados e para o raro uso da botica² ${ }^{2}$.

A doçaria produzida nos conventos surge motivada por um contexto histórico, económico e sociológico: a abundância do açúcar, o apogeu das casas religiosas na vitalidade religiosa associada à contrarreforma e, sobretudo, uma abundância de "mão de obra", as mulheres que povoam os mosteiros forçadas pelas constrições do regime de morgadio que lhes impunha o celibato ${ }^{3}$. Essas jovens, de condição social elevada e acompanhadas pelas suas criadas, dedicam o seu tempo a criar e a compor as artes acessíveis às mulheres: o bordado e a costura dos panejamentos litúrgicos e eclesiásticos, os recortes em papel, a doçaria. Com esses produtos, relacionam-se com a sociedade envolvente e, em particular, com a doçaria, tão apreciada ao gosto do Portugal seiscentista:

[...] atrai à roda dos conventos uma chusma de freiráticos, de estudantes, de clérigos, de poetas, todos em jocosos encontros que se alimentam de [...] uma literatura repentina e amorosa, de compotas e doces de colher, de bilhetes audaciosos, bolos, cartas de nó, gargantas de freira, papos de anjo, marmeladas... é neste processo de trocas e afoitezas,

2 Sousa 2013: 14. Saramago 2000: 16. Nos inícios do séc.XX, um discurso dietético moralista acusava o açúcar de ser responsável "pelo envenenamento do pensamento da época, causador de produções literárias imorais, romances delirantes, músicas contorcionistas, pintura desarmoniosa, modos selvagens". O gastrónomo conclui a introdução desse volume com um repto em que identifica, mesmo na mentalidade contemporânea, esta transferência entre a procura do doce alimentar e a liberdade sexual: "Não queiram retirar o prazer do nosso horizonte, e não queiram também confundir-nos, aproveitando a liberalização do sexo, para ensaiar a crescente repressão do açúcar”.

3 Saramago 2000: 24-37. As filhas segundas, ou das que não casavam, ou que tinham contratempos na sua vida privada provinham das classes abastadas ou aristocráticas e transportavam para o mosteiro o gosto e as práticas gastronómicas das elites; p. 26: "os doces como símbolos de convivialidade tomavam conta dos ócios e dos interesses das monjas”. Sousa 2013: 9-24. A maioria dos mosteiros teve proteção de reis e nobres que "[...] usavam os doces como instrumentos de representação social .... representação do prazer e do luxo”. 
brilhos e mensagens, de mundanidade, que se transfigura o doce e que ganham amplo significado os trabalhos da clausura e os resplendores da cozinha seiscentista portuguesa (Soares, P., op. cit.: 35).

Desse modo, encontra-se a motivação para essa doçaria conventual nas circunstâncias históricas e sociais externas, aliadas a uma explicação psicológica: o fabrico dos doces e o seu comércio eram fruto de uma vivência algo contrafeita, uma compensação para uma vocação sobretudo imposta, que, dessa forma, procurava caminhos de escape para uma sexualidade reprimida e, pelo comércio e trocas, acesso a uma mundanidade sensorial que os rigores do claustro e da vida espiritual deviam inibir ${ }^{4}$. Assim, a antroponímia nas designações dos doces e a delicada e conceptual antropomorfose que neles se observa (as Gargantas de Freira, por exemplo, simulam um colo branco, estreito e macio, talvez alusivo aos colos brancos e ao entoucado dos hábitos monásticos femininos) são fruto de uma estratégia de substituição, em que o nome e a matéria do doce preenchem a necessidade íntima de afeto e de fisicalidade que o claustro lhes retirou. Profundamente ligados ao universo feminino, as Gargantas de Freira, os Colos de Freira, os Papos de Anjo, os Cabelos de Anjo, as Barrigas de Freira, os Peitinhos de Noviça, os Beijinhos de Freira, as Maminhas de Freira ${ }^{5}$ preenchem esse imaginário povoado de freiras "assim não tão virtuosas" que dão azo a uma sexualidade recalcada num ambiente social de época descrito como permissivo e dissoluto ${ }^{6}$.

Do ponto de vista do marketing da doçaria conventual portuguesa atual, essa explicação é bastante sedutora. Traduz-se muitas vezes na caricatura, no anedótico de apresentar os doces num cenário jocoso e picante, em que a vender ou a expor os doces encontramos senhoras vestidas de freiras, que encantam os passantes com a visão e a degustação dos doces, tom que teste-

${ }^{4}$ Saramago 2000: 29-32. Entre as razões para a entrada no convento, a menos documentada é a da vocação religiosa. Id. 33-34 afirma que a riqueza da doçaria conventual decorre de fatores externos ao da vocação religiosa ou do ambiente sagrado: "As saudáveis condições económicas dos conventos, conjugadas com as razões para a entrada nos claustros, muitas vezes afastadas de qualquer vocação e motivadas por questões de vida secular, nem sempre conseguiam instalar nas casas monásticas um ambiente de fé e de oração".

5 Id. Os doces tinham nomes amorosos e até eróticos. Suspiros, peitos de freira, beijinhos, sonhos, papos de anjo do céu e manjar branco são exemplos. "O manjar branco" era o mesmo do que os peitos de freira. Era um creme branco, em cujo topo se punha um fio de caramelo, para dar a forma de um bico de seio. E não era para comer à colher, mas sim para lamber. A maior parte desses doces, além de constituir sustento do convento, também servia de pagamento a poetas e estudantes que todas as tardes iam aos muros declamar poemas e tentar seduzir as freiras. Chamavam-se as tardes dos outeiros. Era pedido às freiras segredo sobre a confecção de certos doces. "As que saem do convento rezam a Deus para não caírem na tentação de o revelar e as que entravam rezam para os fazerem bem.” O Manjar Branco é feito a base de farinha de arroz, peito de frango cozido, leite, açúcar e casca de laranja.

6 Saramago 2000: 33-34. 
munhamos nas mostras e feiras de doçaria conventual que percorremos nos últimos dois anos, em Coimbra e em Alcobaça.

Colocamos a possibilidade de essa abordagem estar aquém da complexidade do fenómeno. Não o sendo, parece-nos, em todo o caso, ferida por um certo sexismo: um anjo redondo num retábulo, esculpido em pedra ou talhado na madeira e coberto de ouro, é uma obra da técnica e da arte do artista entalhador que se exprime nos códigos estéticos do estilo barroco; mas um anjo, um colo esculpido em açúcar e ovo, ou uma onomástica alusiva a partes do corpo para designar um produto gastronómico num convento feminino é obra do devaneio erotizado de um ambiente feminino, cuja explicação principal reside no facto histórico incontestável de acesso à matéria-prima e no facto sociológico e cultural de vocações religiosas contrariadas.

Estaremos nós, limitados a essa explicação, a apoucar estes "produtos" de lavra feminina, sejam eles lavores, sejam doces, não os considerando como uma legítima expressão estética e artística tão digna e tão capaz de comunicar um ambiente cultural e religioso como o que reconhecemos existir no conceptualismo, no jogo lúdico de contrastes e na imaginação sensualista do barroco literário; ou, no plano das artes visuais, no gosto pela exploração assimétrica dos volumes, pelo colorido e pelo emotivo, pelos contrastes de sombra e claridade, pelos jogos de perspetivas, pelo emotivo e horror ao vazio que encontramos na pintura, na decoração e na escultura barroca?

Os produtos de gastronomia próprios de uma época, tal como determinadas artes decorativas (a decoração dos espaços interiores, os arranjos de flores, as rendas e os bordados, os recortes em papel), são, na sua própria natureza, bens efémeros, com durabilidades variadas, pelo que pode residir na efemeridade destas manifestações a causa para a sua não inclusão como participantes num movimento estético e artístico mais vasto. Perecíveis e difusos na observação, com maioria de razão, os produtos alimentares estão sujeitos a uma efemeridade que ultrapassa os meros fatores erosivos proporcionados pelo desgaste do tempo: o doce que se faz destina-se a desaparecer, a ser comido, pelo que no seu curto processo de existência, que inclui o fabrico e o consumo, deve cumprir o seu propósito, comunicativo, lúdico, espiritual e artístico. A efemeridade, portanto, deveria traduzir-se, neste caso, como um fator de concentração dos propósitos do objeto que se quer comunicar, e não na sua superficialidade ou no seu caráter pouco preciso.

Reparemos, mais ainda, que essas manifestações ditas “menores” são, na sua grande maioria, obra feminina. Isso as irmana também, por circunstâncias várias: às mulheres, por educação, por tradição familiar, por papéis sociais definidos, foram historicamente reservadas as práticas culturais e artísticas que implicavam manuseamento de matérias-primas mais leves, ou próprias do interior das casas, das famílias e dos conventos. Aprender a bordar, a costurar, a tecer, a decorar e a cozinhar foram historicamente as artes permitidas e 
desenvolvidas pela maioria anónima das mulheres, com notáveis exceções de algumas que se individualizaram na escrita, nas artes e nas ciências.

\section{Para uma nova fundamentação da doçaria tradicional: da CIRCUNSTÂNCIA RELIGIOSA À ESSÊNCIA DO SAGRADO}

Mas os anjos continuam a estar lá... se nos libertarmos do caráter efémero e da autoria feminina na criação das artes gastronómicas implicadas na produção do doce conventual, podemos vislumbrar a presença de uma coerência e de uma continuidade estética e artística entre as várias linguagens em que o estilo barroco se exprimiu, seja a literária, a plástica ou a efémera. A doçaria conventual é assim um produto artístico desenvolvido num ambiente histórico e cultural, e as suas manifestações, os doces, podem ser legítimos portadores de uma sensibilidade estética e de uma expressividade artística que os torna coerentes entre si, participantes de um código e capazes de comunicar modos de sentir e de pensamento que consideramos próximos da grande estética barroca.

Deslindar as unidades significativas desse código, na sua multiplicidade de estímulos sensoriais envolvidos (visuais, olfativos, tácteis, gustativos) e na sua construção enquanto objeto cognitivo individualizado (neste domínio, o nome e o conceito associados ao doce exercem um papel fundamental na leitura do mesmo enquanto objeto significativo) e permanente enquanto imagem intelectual são tarefas de uma análise estruturada que urge fazer para uma apresentação do significado do doce em si, para além de um condicionalismo externo histórico e sociológico que, como mencionámos, o reduz essencialmente a um pretexto.

Alguns indícios nos serviram de guia acerca de outras motivações para a doçaria conventual. Apontamo-los aqui, cientes de que constituem hipóteses a merecer aprofundamento e porventura contraditório, mas, em todo o caso, linhas a ter em conta num aprofundamento desse estudo.

Em primeiro lugar, a doçaria conventual é um produto de valor económico crescente. Não se trata, contudo, de uma tradição estática: as formas de apresentação dos doces, assim como as suas designações, têm vindo a diversificar-se e a evoluir num sentido que lhes reforça a carga erótica, num registo cada vez mais antroponímico e antropomórfico, pensamos que essencialmente por estratégia comercial ${ }^{7}$. Em segundo lugar, o estudo dos documentos de época,

7 Percorridas as obras de A. Saramago, P. Tavares, D. Sousa, E. Ribeiro e C. Conseglieri, que muito fizeram pela divulgação da tradição histórica da doçaria portuguesa ao editarem o seu receituário, constata-se que os nomes dos doces são muito variados, havendo entre eles os nomes de estados de espírito (e.g. Melindres, Suspiros) de actos humanos (e.g. Beijinhos de Freira) e de partes do corpo (e.g. Papos de Anjo, Orelha de Abade), mas não são maioritários. Os mais abundantes são aqueles que aludem a uma origem (e.g. Marmelada de Odivelas, Biscoitos 
assim como dos textos literários que testemunham o ambiente de circulação dos doces conventuais fora dos mosteiros inseridos numa mundanidade de trocas sociais e afetivas, são fundamentalmente produzidos pela sociedade secular ou por agentes exteriores ao mosteiro ${ }^{8}$. Não são as habitantes dos mosteiros quem promove estes discursos, nos quais elas, os doces e o ambiente monástico feminino em geral são um objeto de que se fala. Acrescentemos, em terceiro lugar, o facto de a história das instituições religiosas em que nasceu a tradição da doçaria conventual ter sido atribulada. As guerras liberais e a extinção das ordens religiosas traduziram-se numa decadência económica e perda do valor simbólico destas estruturas nas comunidades. O saber doceiro converteu-se, com mais necessidade ainda, em fonte de proventos materiais para comunidades depauperadas, e a progressiva envolvência de auxiliares seculares para o comércio desses produtos, que se tornam mais acessíveis e mais democratizados no seu consumo9. Essa maior permeabilidade entre o convento e o exterior contribuiu para a divulgação dessa tradição e para a sua passagem, enquanto produto a ser fabricado, para o exterior não monástico. Temos, portanto, uma evolução no contexto de receção do doce, em que esse surge, no seu consumo, desenquadrado do código significativo de espiritualidade em que nasceu. A colocação do produto no mercado, contudo, obedece a uma transformação no seu modo de servir, na sua aparência e se lhe associa uma história, uma mitificação acerca da origem da "ruptura do segredo" da qual, em geral, as pessoas consagradas não saem bem tratadas: ou foram as criadas das cozinhas que trouxeram com elas o saber-fazer, uma vez

da Abadessa, Pastéis de Santa Clara) ou ao processo de fabrico (e.g. Peras Escorchadas; Leite Azedo). No entanto, hoje distinguem-se pelo seu sucesso comercial e popularidade aqueles que são lidos como transmissores de uma sensualidade inerente aos doces (e.g. Barriga de Freira, Peitinhos de Freira, Colo de Freira, Papo de Anjo etc). Evolução evidente ocorre com as Barrigas de Freira e o Manjar Branco: as suas versões históricas são doces de tijela. O primeiro circula em forma de pastel e, quando em tijela, a decoração com canela procura, entre algumas confeitarias que visitámos, reproduzir o umbigo e a distribuição de pelos púbicos num ventre feminino, no que pensamos ser uma recriação que nada tem de ver com a forma primária quando, na sua intencionalidade, o procurou ser (isto é, recuperar a apresentação de doce de colher original). O Manjar Branco é o mesmo doce que é hoje vendido também com os nomes de Maminhas de Noviça ou Peitinhos de Freira, em doses individuais que permitem uma melhor venda e distribuição de um produto que era de tijela e de colher.

8 Salientamos dois registos, um que podemos classificar como legal, acerca das sanções de que foram alvo quem frequentava indevidamente o claustro e a companhia das freiras (Saramago 2000: 33-34, os testemunhos de Frei Caetano Brandão, do padre Inácio Mendes, do Frei António, capelão do convento de Santa Clara de Portalegre); e outro literário, em teatros de cordel ou em poesia jocosa e palaciana Tavares 1999: 11-42 (em particular 15-42) apresenta testemunhos literários focados em episódios mundanos vividos num ambiente "freirático", de homens que frequentavam ou se sentiam atraídos pelos doces e pelas graças das freiras.

9 Sousa 2013: 20-24. A decadência económica das casas monásticas após 1834 leva as suas ocupantes a converterem o seu saber em "trabalhos de mão" como fonte de proventos, vendendo os seus produtos. 
libertas do ambiente monástico, ou se fala na "freira gulosa" que disfarçava o seu grande apetite por doces com a sua pretensa qualidade medicinal ${ }^{10}$. Entre o séc. XIX e o séc. XX, mais ainda após a revolução republicana, Portugal viu desenvolver-se, entre as elites intelectuais fazedoras da opinião pública, nos jornais ou em escritos literários, mas também num registo popular, um anticlericalismo que revia negativamente a influência da Igreja regular na história de Portugal ${ }^{11}$. Não discutimos a justeza ou a injustiça desta imagem negativa deixada por esses monges e monjas na opinião popular, apenas a constatamos como, a nosso ver, uma circunstância favorecedora de um discurso tendente à promoção das obras (isto é, das artes e dos produtos) da cultura monástica como fruto de ambientes corrompidos ou pouco piedosos, quando a erosão dessa piedade e da lógica interna de um mundo coeso como era o do interior das casas monásticas se construiu. essencialmente, e por vozes hostis, após a decadência e a extinção do mundo conventual.

Em quarto lugar, registe-se a porventura ausência de uma leitura universal para o enquadramento do caso português, que nos parece existir. A doçaria conventual constitui um património português de inegável riqueza e complexidade nas suas manifestações, mas, noutros lugares, noutras culturas e noutros tempos, nós encontramos alimentos associados a uma prática ou uma cultura religiosa, assim como, dentro desse uso sagrado para os alimentos, distinguem-se os produtos doces como um importante subtipo alimentar, usado como um instrumento de acesso ao sagrado. Os exemplos espalham-se por várias geografias e culturas, mas o que nos interessa mais aqui evocar, até pelo seu caráter de proximidade e de contiguidade com o fenómeno da doçaria conventual, é o da doçaria popular portuguesa, o outro par que compõe a doçaria tradicional.

A doçaria popular portuguesa manifesta casos de integração em festividades religiosas, no sentido em que é por ocasião da celebração de um momento litúrgico ou da comemoração de um santo que se proporciona o fabrico, a venda, dádiva ou troca de um produto particular, na sua maioria doce. A forma antropomórfica desses doces (figurações de pessoas ou de partes

${ }^{10}$ A história da origem dos "Pitos de Santa Luzia", doce popular de Vila Real, com origem no Convento de Santa Clara. Reza a lenda que uma freira muito gulosa, proibida pela madre superiora de se aproximar de doces, concebeu este disfarce em forma do pacho com que se aliviariam os males dos olhos (sendo Santa Luzia a protetora da visão). Temos, nesta história, os indícios da evolução na receção do doce. Criado no convento, é divulgado na comunidade acompanhado de uma mitificação da origem. Entre o convento e a comunidade perderam-se sentidos, e ganharam-se outros, que pertencem mais à cultura de receção do que à da origem. http://www.cm-vilareal.pt/index.php/conhecer/pastelaria-tradicional.

11 Acerca do anticlericalismo em Portugal, ver Catroga 1988: 211-273. A lenda da origem da Sopa da Pedra, ou as figuras obscenas de barro dos frades em que, puxando um cordel, se ergue do hábito um falo priápico, da tradição caldense, são afloramentos desse anticlericalismo sedimentado na memória popular. 
do corpo), a par de uma onomástica sugestiva e, por vezes, de uma narrativa explicativa acerca daquela particular tradição, permite uma leitura também sensual, senão erótica, do doce popular. A explicação mais corrente é a da inserção de rituais ancestrais de celebração da abundância e da fertilidade num calendário e num ciclo de festas formalmente e, de certo modo, superficialmente cristianizado ${ }^{12}$. Portanto, a antroponímia e o antropomorfismo que a doçaria popular partilha com a doçaria conventual, mesmo havendo cruzamentos e interação entre as duas culturas, gerando produtos diversamente motivados e elaborados na sua origem e em ambientes também diferentes, constituem, para nós, um bom indício para a procura da motivação nuclear do doce conventual naquilo em que ele se identifica com a doçaria popular. Pensamos que a ninguém caberia dizer sobre a doçaria popular - que tantas vezes faz apelo à sugestão erótica ou mesmo à explicitação obscena, feita de subentendidos e de metáforas que acompanham o seu consumo - que esta associação entre o caráter doce e a evocação sensual ou corpórea é fruto de um ambiente recalcado, de transferência de pulsões reprimidas para as manifestações possíveis e socialmente aceitáveis do fabrico dos doces. Na doçaria popular, temos exatamente o contrário: essa evocação erótica encontra-se ao serviço de uma linguagem transgressiva excecional, em que se celebra a vida, a abundância e a fertilidade, num ambiente socialmente liberal e que aceita, por algum momento, a transgressão e a troca de favorecimentos metaforicamente sexuais. Retomemos o exemplo do "Pito de Santa Luzia", doce corrente nas pastelarias de Vila Real, mas que a tradição manda que seja oferecido pelas raparigas aos rapazes no dia de Santa Luzia, troca de doces esta que é precedida pela doação dos rapazes às raparigas da "Gancha de S. Brás", no dia da festa do Santo.

Esta capacidade de o doce integrar a linguagem da gratificação sob uma forma e uma designação antropofágica foi também enunciada pelo antropólogo e estudioso das religiões Raul Lody, considerando o caso brasileiro e o caso

12 Ribeiro 1997: 29-32: "em alguns desses doces podemos verificar influências ancestrais do paganismo em que os emblemas da fecundidade e da fertilidade se patenteiam a cada passo. Muitas formas de pão doce, ainda hoje, mostram-nos claramente a mesma origem. Assim a par dos bonecos de doce existem os doces de romaria [...]". Os "belindres, os velhotes, as passarinhas (na Madeira, os melrinhos), os sardões”, os biscoitos de orelha, os pitos, as ganchas, as ferramentas de S. Gonçalo são bolos de massa doce (farinha, ovos e açúcar na sua base), com uma forma alusiva a partes do corpo, algumas de conteúdo erótico, visível tanto no nome como na forma do doce. Em 1957, Pessanha, D., Doçaria Popular Portuguesa (consultámos a ed. de 1997, revista por Ferreira V.) apresentou um pioneiro estudo etnográfico sobre a distribuição geográfica e riqueza de formas dos doces de romaria, com fotografias de casos hoje desconhecidos ou raros de encontrar. Destacam-se os bolos de forma antropomórfica (o corpo inteiro, partes do corpo) e zoomórfica. 
português ${ }^{13}$, estabelecendo ele a mesma expressão antropofágica na doçaria conventual e na doçaria popular.

Num e noutro caso, identifiquemos o momento da ingestão e da partilha do doce como uma ocasião de celebração e de gratificação, em que há lugar a "trocas" de dádivas, gentilezas, presentes como manifestação de vínculo social, afetivo e religioso, num momento formalmente destinado à celebração do sagrado. Ele parece-nos evidente no caso dos doces em festas e romarias populares, mas pode também estar presente - devidamente teatralizado e encenado, atendendo ao estatuto social dos envolvidos - nas práticas de oferta de doces aos visitantes, aos protetores nobres e eclesiásticos dos mosteiros. Isto é, para além de um ritual social de convívio próprio de uma época farta, podemos ver nas transferências de doces para os que não pertencem ao espaço fechado do convento uma função religiosa ancestral associada aos doces, que é a da restauração da felicidade e de um momento de prazer, como identificou A. Rios ${ }^{14}$.

Dessa forma, somos levados a procurar outros fundamentos que, não excluindo a justeza das explicações já existentes, colocam a montante - ou seja, naquilo que, na sua essência e para além dos circunstancialismos históricos e sociológicos, existe em comum, remotamente e por vezes esquecido - entre a doçaria conventual e a doçaria popular. Nesta unidade, identificamos, em primeiro lugar, o sabor doce. Em segundo lugar, a inserção desse produto

13 Lody R. "Quando comer doce significa comer gente, ou uma doce antropofagia" in Malagueta Comunicação blog. "Por mais que, inicialmente, pareça remoto, há um forte vínculo de ideal antropofágico na doçaria. Diga-se na procedência e na ancestralidade dos conventos medievais de Portugal, que de maneira sensual e também erótica oferecem ao paladar público, por exemplo, uma barriguinha de freira. Doce de cor muito branca como, certamente, pode-se imaginar uma barriga de freira, que nunca vai ao sol, sempre protegida pelos muitos panos do hábito. Esse doce, uma sobremesa muito conhecida no Brasil, nasce de massa fina e branca, como um pastel de hóstia, quase transparente, e é recheado com doce de ovos, segundo a melhor tradição portuguesa”. (Disponível em: < http://www.malaguetacomunicacao.com.br/noticia/ quando-comer-doce-representa-comer-gente-ou-uma-doce-antropofagia>, Acesso em: 23 set. 2015).

${ }^{14}$ Rios 2015 in Goldstein: 17-20: “[...] have, over the centuries, been prepared, bought, and exchanged as presents that add significance to convivial, pagan, and religious celebrations. A wealth of creatures, or parts of their bodies, convey symbolism from the most remote, even pre-totemic times. These sweets are highly aesthetic, as well as delicious and diverse in their ingredients, techniques, intentionality, and meanings. Often they are employed as messengers of mythological beliefs, pagan legends, or episodes of biblical origin, shared through oral tradition and now embedded in updated imagery and practices. [...] Zoomorphic and anthropomorphic sweets remind us who we are and where we come from. These edible metaphors, vestigial markers of identity often closely tied to festivities, combine tradition with innovation and encourage collective indulgence, as if to prove the truth of the adage 'You become what you eat and survive from what you sell.' Whether homemade or bought from convents, stalls in fairs and markets, or from bakeries and cake shops, these ritual sweets offer an opportunity for families and friends to gather and celebrate". 
num evento, num espaço ou num tempo sagrado de festa. $\mathrm{O}$ que deve ser explorado, de facto, é a funcionalidade do doce enquanto presença ativa de um evento ou uma circunstância religiosa.

\section{DECOMPONdo O DOCE TRADICIONAL NOS SEUS ELEMENTOS ESTRUTURANTES}

\subsection{O doce}

Quanto aos constituintes do doce tradicional, identificámos o produto e o sabor de base que é o açúcar ${ }^{15}$. A essência da doçaria é... o sabor doce. Esse é um luxo da natureza, encontrado naturalmente em algumas raízes (a beterraba, a cenoura), nos frutos e no mel, com graus variados de concentração. Por que produz a natureza o sabor doce? Não o faz, certamente, a pensar nos devoradores de pastéis do séc. XXI. O sabor, em si, insere-se dentro das estratégias ecológicas de conservação e de preservação da energia em forma de hidratos de carbono. Frutos, sementes, raízes e mel constituem, em graus de eficácia diferentes, modos de armazenamento de energia para a vida que prossegue nas novas criaturas, vegetais e animais. No caso humano, aceder ao doce foi, durante os milénios da história do homem primitivo, resultado de uma hábil demanda de recolector, que assim compensava a sua dieta carente de calorias com o acesso à sua fórmula de chegada, concentrada, fácil e segura de ingerir ${ }^{16}$. O ser humano está fisiologicamente preparado para apreciar o doce (o leite materno é doce), e a este sabor não se associam venenos ou perigos alimentares, como no caso do sabor amargo ${ }^{17}$. Além disso, o acesso ao doce não implicava comportamentos de predação, antes de recoleção e de perícia na sua localização e colheita. Por outro lado, trata-se de um sabor

15 Galloway "Sugar” in Kiple, Ornelas 2000: 449-437. O açúcar é hoje o adoçante principal, posição conquistada a partir de 1700 .

16 Cohen 2000: 63-69 in Kiple, Ornelas, fala da dieta do caçador recoletor como uma dieta com uma textura fibrosa destinada a partir, mastigar, triturar, sejam os animais, sejam as plantas, com pouca concentração de energia face ao volume de alimentos transformado. Esta dificuldade mecânica de extrair os nutrientes dos alimentos explicará uma longa fase de aleitamento materno para as crianças humanas, ou mesmo estratégias de pré-mastigação pelos adultos cuidadores, num caso e noutro com consequências no fortalecimento dos laços entre as gerações e as comunidades humanas. A excepção, de consumo muito ocasional, é o mel, que é fácil de ingerir, com uma grande concentração calórica.

17 Rozin 2000: 1477; 1476-1486 in Kiple, Ornelas identifica uma tendência inata e uma programação genética de muitas espécies, em particular omnívoros, para ingerir alimentos doces, relacionados com um aporte calórico percebido como superior, e para evitar alimentos amargos, relacionados com a presença ou identificação de toxinas percebidas como perigosas. Este saber, associado aos gostos doce e amargo, é reforçado pela aprendizagem da procura de alimentos em transmissão social na comunidade. Também Moskowitz 1971: 387-405 apresenta um estudo em que, desenvolvidos testes laboratoriais com vários tipos de açúcares, mede a sua capacidade de gerar as chamadas "funções de prazer". 
a que se pode aceder sem aplicação de técnicas de cozimento ou mesmo de conservação - acede-se ao seu potencial nutritivo do mel, do néctar das flores, dos frutos, das raízes ou caules doces comestíveis sem ser preciso fogo.

O doce, em termos de alimentação humana primitiva, está, por isso, nos antípodas do valor da carne: esta tem de ser perseguida, cercada e morta após programadas e coletivas estratégias, cozinhada para dela retirar o máximo potencial nutritivo, guardada e defendida de outros predadores. Processo laborioso e complexo, com uma perigosidade real a ela associada, o homem libertou-se da sua dependência alimentar face à recoleção e à caça com a domesticação dos animais e das plantas: pastorícia e agricultura representaram avanços civilizacionais que sustentaram o desenvolvimento dos homens em comunidades complexas, hierarquizadas, capazes de prover recursos previsíveis e de os armazenar, reduzindo o aleatório e os riscos das atividades anteriores. Não obstante esse ganho civilizacional, a fisiologia humana mantém na sua genética a memória desse longo período de irregularidade de recursos: a natureza omnívora e adaptável aos recursos do ambiente e que se está inserido e a propensão para a acumulação de energia sob a forma gordura corporal em épocas de abundância a ser despendida em períodos de escassez são estratégias do nosso corpo para lidar eficazmente com um ambiente de recursos escassos, intermitentes e essencialmente não dependentes da vontade humana.

O sabor doce, contudo, manteve-se associado a um mundo de felicidade, ligado à memória de uma infância em que tudo é dado e gratuito ${ }^{18}$, ou a um paraíso, de que se saiu e a que, em circunstâncias ideais, se pode voltar. Terra onde corre "o leite e o mel" é o lugar prometido aos judeus após o cativeiro do Egipto, a Idade do Ouro da mitologia grega de Hesíodo é o lugar em que os homens vivem rodeados "de bens inúmeros", de frutos abundantes, tal como no jardim do Éden do Génesis. A religiosidade grega e a religiosidade judaica e cristã convergem na conceção de uma idade feliz e doce para o homem, que foi perdida, mas a que se pode voltar (o céu, os Campos Elísios) ${ }^{19}$.

Neste mundo original perfeito, o acesso ao alimento está à distância de um estender de mão e o debelar da fome não convoca a ansiedade do esforço incerto de uma caçada, de uma espera, ou ainda da perturbadora tensão de

${ }^{18}$ Rozin, 2000: 1480 menciona o "primeiro trauma" da vida associado ao desmame, trazendo consigo o abandono, atingido em diferentes tempos e de várias maneiras culturais entre as civilizações humanas, desse "super-alimento" sempre disponível, que expõe o indivíduo ao trabalho e aos riscos de uma alimentação omnívora. Para o ser humano, o consumo de leite mantém-se graças à domesticação de gado, sendo, portanto, uma aquisição cultural.

19 Significativamente, Dalby 2002: 26 integra o açúcar dentro de um capítulo a que dá o título de Exports from the Paradise. Ribeiro 1997: 15 e ss., introdução de Proença, acerca do açúcar e a sua utilização na história moderna e contemporânea portuguesa. 
esta, a minha necessidade de alimento (o sujeito que come), implicar a perda de uma vida do ser que é sacrificado e comido.

O doce constitui, por isso, o alimento da dádiva, do prazer sem a culpa do sacrifício, do afastar rápido da ansiedade da fome sem que tal implique esforço ou trabalho. É o alimento das crianças, do homem antes do pecado, dos deuses que, na mitologia grega, se deliciam de néctar e ambrosia. Assim, Hesíodo carateriza os homens da Idade do Ouro como seres para quem a terra produz (e não seres que trabalham a terra para ela produzir) frutos inúmeros, livres de cuidados, de preocupações e de trabalho. Também o lugar paradisíaco e original da criação do mundo, segundo a mitologia judaica e cristã, repete esse padrão: o primeiro par é criado para habitar um jardim de que pode usufruir plenamente, à exceção do fruto de uma árvore: abundância, despreocupação, ausência de trabalho, de dor e de doença e também da consciência da mortalidade, são predicados que acompanham o homem do paraíso ${ }^{20}$. Terminado esse período transitório de tréguas iniciais entre os deuses e os homens, o homem perde esse estado de graça, e as consequências são conhecidas: a dor, o trabalho, o esforço necessário para colher o pão como metáfora do alimento e da sobrevida ameaçadas. Doravante, no que corresponde à idade madura do homem, este, afastado do convívio dos deuses, conhece as formas de mortalidade que lhe advêm da doença, da fome, do acidente ao tentar alcançar o alimento que resiste e dá luta (na predação), num constante fio da navalha que é a luta pela sobrevivência.

Especificamos, ainda, o manna como um adoçante regional, substância doce que se forma à superfície de determinadas plantas, de árvores a ervas, em certas estações, em particular no Médio-Oriente, nos desertos da Síria e do Iraque, da Arábia e do Egipto. Essa goma doce, assim denominada, provém de diversas origens: gerada por determinados insectos que infestam certas plantas; exsudada da própria planta como reação de defesa às picadas de insetos; ou, ainda, um líquen que se forma à superfície das rochas ${ }^{21}$.

${ }^{20}$ Dias 2015:21-40. Especificamos nas pp. 33-37 a geografia transcendental desses lugares felizes nas culturas clássica, judaica e cristã, espaços de que o homem brotou e a que o homem deseja regressar, marcados pela abundância e pela doçura alimentar, a par da ausência de trabalho e de sofrimento

21 Davidson 2006: 449. Manna é uma substância doce correspondente a três produtos diferentes. A planta do tamarisco (tamarix manifera ou tamarix gallica) segrega uma seiva após a picada do inseto coccus manniparus ou do trabutina mannifera. Mann, em Árabe, se designa taranjabin, "mel fresco, mel da manhã" em Persa, gezo entre os Curdos e no Norte do Iraque. É comercializado sob a forma de uma massa cinzenta e pegajosa, que se dissolve em água a ferver e se purifica com ovos. É preparado fervendo a água e dissolvendo nele o produto, xarope de glucose e frutose. O xarope daí resultante é transformado com ovos e adição de algumas amêndoas. Pode-se ainda usar o Espinheiro de camelo (alhag maurorum), essencialmente sucrose que se colhe sacudindo os ramos sobre um pano. Um outro produto a que se chama de manna é um líquen que se forma nas rochas em determinadas condições climáticas (Lecanora esculenta). 
Não cabe aqui discorrer sobre a identificação entre o maná que surge no $\hat{E} x o d o$ e em Números, um superalimento que saciou os hebreus errantes no deserto, e o maná das práticas alimentares do Médio-Oriente. Diz o texto que ele se formava como uma substância granulosa visível no solo após a dissipação do orvalho. Facilmente deteriorável, o sol derretia-o e não se podia guardar para o dia seguinte, cabendo a cada um colher o bastante para esse dia. Tinha o aspeto das sementes de coentro e o sabor de tortas de azeite. Não há uma menção especial ao sabor doce associado ao maná no texto bíblico. A comparação que mais sobressai, entre o maná, que não se sabe o que é, e um produto alimentar, é com "pão", ou bolos, moídos e cozidos, ainda que com caraterísticas especiais, pois suprimia, juntamente com as codornizes, toda a dieta, apesar de a monotonia alimentar ter sido, mesmo assim, causa de fastio e de murmuração entre os Hebreus (Nm 11, 4-8). No entanto, o maná bíblico e o manna das práticas alimentares do Médio-Oriente partilham com os alimentos doces mencionados (o mel, os frutos) o facto de resultarem da recoleção e o terem um estatuto misterioso de dádiva, ou de graça, também reforçado pelo desconhecimento que o homem teve, historicamente, dos processos naturais que criam o mel e que fazem emergir sazonalmente os frutos.

\section{$3.2 \mathrm{O}$ ovo}

Além do doce dado pelo açúcar, outro importante ingrediente constituinte do doce tradicional é o ovo. Uma das explicações frequentes para a abundância do uso do ovo na doçaria tradicional encontra-se na disponibilidade e na acessibilidade do produto: os conventos recebiam rendas em espécie, aves de capoeira e ovos, fáceis de criar e obter nas comunidades rurais e urbanas; além disso, eram usados, sobretudo as claras, para engomar e tratar as roupas usadas pelo clero.

Mas o ovo é também uma dádiva gratuita, no sentido em que não implica a morte da ave que o põe. Tal como o leite dos mamíferos usado para consumo humano, estamos em face de dois produtos biologicamente integrados em determinadas fases do círculo reprodutivo das espécies de que as culturas humanas retiraram a externalidade de os integrar na sua cadeia alimentar. Tanto um como o outro, reparemos, são produtos alusivos a uma fase inicial da vida de aves e de mamíferos: o ovo transforma-se num pintainho, o leite alimenta as crias imaturas dos mamíferos. E, por isso, um e outro são alimentos

Os nómades sírios chamam-lhe "gordura da terra", e serve para fazer um tipo de pão e uma geleia. A identificação entre o maná, alimento milagroso e completo que cai no acampamento dos Hebreus no deserto (Ex. 16; Nm11, 6-9) e esses produtos reais não é evidente, tanto que estes suplementam uma dieta com o sabor doce e são percebidos como uma iguaria ocasional, enquanto o maná bíblico garantiu o sustento do povo no deserto durante quarenta anos. 
altamente nutritivos e completos, com as proteínas, a gordura, os açúcares e as vitaminas equilibradas.

O ovo representa também, para os animais, aquilo que o fruto é para as plantas: o embrião de uma nova vida que despoleta, a promessa, a juventude, um estado primitivo cuja transformação dará origem a um novo ser.

A tradição de oferecer, trocar, procurar ou comer ovos, que subsiste com vigor na celebração da Páscoa nos países cristãos, representa a absorção de um fundo primitivo, caraterístico das zonas temperadas do hemisfério norte, na Eurásia, que celebrava a chegada da Primavera com esse dom propiciatório de vida como ponto de partida, num estado de pureza embrionária e indistinta. Assim, a festa móvel da Páscoa, celebrada na primeira lua cheia após o equinócio da primavera, encaixa-se na linguagem religiosa do calendário astronómico desde tempos remotos. Os ovos que integram a massa ou que enfeitam os folares portugueses, os ovos de chocolate ou de tipos diversos, de pastelaria, os ovos cozidos ricamente decorados do leste da Europa, os ovos-joia das oficinas Fabergé são manifestações dessa simbologia ${ }^{22}$. Tradição maioritária entre nós, as próprias amêndoas que se oferecem e trocam na Páscoa, em particular entre padrinhos e afilhados, uma camada de açúcar que banha e esconde a semente da amendoeira, assumem a forma exterior, o aspeto, a morfologia e, quanto a nós, a simbologia do ovo, visto que o açúcar endurecido é a casca e a semente no seu interior é o embrião. O cristianismo propõe também a sua visão própria para a simbologia do ovo na Páscoa, representando o túmulo vazio de Cristo após a ressurreição.

\subsection{Os frutos}

Ainda dentro dos constituintes principais da doçaria tradicional, em particular a conventual, salientemos o uso de frutos. A doçaria conventual serve-se com abundância da amêndoa, fruto seco inserido nos hábitos alimentares dos países do arco mediterrânico, juntamente com outros: o pinhão, a noz e a avelã. Antes da democratização do açúcar, os frutos substituíam o mel como doce mais acessível e alternativo, e também integram essa escala de referentes alimentares do paraíso: os frutos colhidos são doces e a sua obtenção não mata a planta que os produz. Como sabemos, aliás, com a transformação

22 Luard 2001: 242-250, acerca dos ovos nas festividades religiosas, p. 234: “in medieval times, eggs were offered as Easter thithes to landlords, both secular and spiritual [...] some cultures - mostly those of Mediterranean - bake whole eggs into their Easter breads, while others, particulary germans and austrians, bake their in the form of figures of animals, with the egg forming the head"; p. 234, os ovos pintados da Páscoa ortodoxa no Leste Europeu. Chevalier 1982: 497. O ovo é o símbolo da renovação periódica e da fertilidade da natureza, confirma e promove a ressurreição (M. Eliade, Tratado da História das religiões), mas também um desejo do regresso a um estado primordial da vida. 
desses frutos, em particular das uvas, podia-se produzir adoçantes alternativos ao mel, como sendo o defrutum ou o passum romanos.

Percorridas as coletâneas de doçaria histórica a que acedemos, estamos em crer que as realizações atuais da doçaria conventual restringem bastante a paleta de frutos que eram usados nas versões mais antigas, apresentando-se hoje estas como combinações de proporções diversas e distintos modos de cocção de uma paleta relativamente monocórdica de açúcar, ovo e amêndoa. Os citrinos são usados como aromatizantes (laranja, limão), mas, historicamente, as maçãs, as pêras, os pêssegos e as ameixas (lembremo-nos da tradição sobrevivente das ameixas de Elvas) conservavam-se em compotas ou envolvimentos de açúcar de consistência diversa ${ }^{23}$.

$\mathrm{O}$ interesse em conservar os frutos, potenciando o seu poder nutritivo e o seu sabor, decorre, naturalmente, de uma boa decisão económica de manter recursos cuja frescura perece ao fim de um tempo e cuja sazonalidade gera picos de abundância alternados com períodos de escassez ${ }^{24}$. Mas o fruto é, sobretudo, como o ovo, o invólucro altamente nutritivo e protetor da semente no seu interior, que em estado embrionário vê assegurada a sua sobrevivência até que ganhe raízes no solo ${ }^{25}$. O fruto esconde e protege com um envolvimento doce a preciosa semente, como uma caixa, como um ninho, como um ventre materno.

\subsection{Mimetização e recriação das origens}

Entre o doce proporcionado pelo mel, o açúcar, os ovos e os frutos há, assim, uma coerência simbólica mimética: associados aos estados iniciais da vida, a sua obtenção implica sobretudo recoleção e o não sacrifício da vida emissora. Essa mimese manifesta-se também na composição final do doce a partir desses produtos: usados em proporções variadas e construídos de modos diversos, são os elementos primários e estruturantes de uma composição final que é a criação de um doce enquanto obra de cultura e arte humana que, assim, reconstitui na sua linguagem os elementos primordiais, o fruto ou o ovo: são as "castanhas doces"; são as "amêndoas da Páscoa". São ainda, mesmo que não transportem o nome, todos os doces de formas arredondadas, regulares,

${ }^{23}$ Braga 2004: 12, 16. A Autora edita o primeiro livro de Doçaria impresso em Português, de 1788, A Arte Nova e Curiosa para Conserveiros Confeiteiros e Copeiros e, entre os ingredientes mais abundantemente usados, temos os frutos frescos.

24 Davidson 2006: 322, acerca da transformação dos frutos por secagem, ou pelo calor, com junção de açúcar, até obter geleias e compotas, modos não sofisticados de conservação por destruírem a forma original do fruto, e a cristalização, como um modo mais sofisticado que lhe preserva a aparência.

25 Chevalier 1982: 340. O fruto é o símbolo da abundância, que brota da cornucópia ou das taças dos deuses. Como portador das sementes, o fruto é, segundo René Guénon e Mircea Eliade, seu discípulo, o "ovo do mundo" símbolo das origens. 
de coloração uniforme dada pelo ovo e o açúcar, restrito a uma forma que se pode pegar com os dedos ou que cabe na mão, numa concentração intensa de um sabor só. $\mathrm{O}$ tamanho dos doces conventuais obedece, naturalmente, a outros critérios que não os simbólicos: é uma pequena e conscrita concentração de sabor na medida da vontade e da capacidade da estimulação humana por uma tão elevada intensidade e concentração de açúcar e de ovo. Estratégias comerciais estão também implicadas no conceito de "unidade" ou de "dose" de um doce conventual ${ }^{26}$. Mas a forma final e o tamanho da maioria dos doces representa, quanto a nós, a morfologia e a constituição reparadora da unidade simbólica proporcionadas pelo favo, pelo ovo, pelo fruto: unidade de sabor, consistência, superfície arredondada e uniforme, facilidade no consumo, diríamos que de uma ou de poucas dentadas só, não sendo necessário o fogo, o aquecimento, grandes baixelas, proporcionando um vislumbre pleno de sensações gustativas. No doce assim (re)composto, nós temos a oferta de um episódio sublime de prazer alimentar proporcionado por uma combinação intensa e concentrada de alimentos da gratificação fáceis de serem consumidos num momento ou num tempo limitado e significativo.

\section{DoçARIA E ESPIRITUALIDADE RELIGIOSA: FUNDAMENTOS LITERÁRIOS E LITÚRGICOS}

$\mathrm{Na}$ busca de motivações para a antroponímia e antropomorfia da doçaria tradicional, além do elemento "doce", identificámos o aspeto religioso. Os doces conventuais e populares partilham essa circunstância emissora de base, sendo os primeiros produzidos em instituições monásticas e os segundos integrando momentos ou festividades religiosas do ano litúrgico (os folares, as amêndoas da Páscoa) ou celebrações do culto de alguns santos (Festa de $\mathrm{S}$. Brás, Festa de Santa Luzia, Festas de S. Gonçalo). O fator religioso não pode, em nosso entender, ser reduzido a uma questão circunstancial - de cenário ou ponto de partida para uma tradição - com a qual não esteja profundamente implicado enquanto gerador de sentidos.

A vida monástica e o ambiente monástico, pese embora variações históricas e de carisma nos modos de organizar a vida de acordo com um propósito religioso, criaram um quotidiano próprio submetido aos princípios basilares e muito práticos expressos na regra beneditina: ora et labora - reza e trabalha, imperativos válidos para todas as comunidades consagradas enquanto atos de edificação, de aprofundamento espiritual e de aperfeiçoamento. Os reli-

${ }^{26}$ As Barrigas de Freira são hoje comercializadas em versão "pastel”, cobertas de uma massa de farinha que facilita o comércio e a circulação do produto, e não na tigela de comer à colher. Do mesmo modo, o manjar branco originalmente colocado em pratos é o ponto de partida das criações posteriores já individualizadas, até nos nomes, dos "Peitinhos de Noviça". 
giosos e as religiosas consagrados cumprem um quotidiano sempre ocupado e predeterminado: rezam e meditam em solidão e na comunidade e fazem trabalhos ou realizam obras de acordo com o carisma da instituição ou o género a que pertencem. $\mathrm{O}$ trabalho servia para prover o sustento do próprio ou para contribuir para o sustento coletivo e, mesmo no caso de as instituições terem recursos próprios de rendas ou de patrimónios legados em heranças, a obrigação do trabalho ultrapassa a questão económica: trabalhar, produzir, fazer ou criar é participar na obra criativa de Deus. Poucas transformações entre o mundo antigo e o mundo pós-cristão na mentalidade ocidental foram tão significativas como a valorização do labor, do trabalho, como uma atividade edificadora e fonte de virtudes em vez de uma atividade servil, própria dos pobres e dos escravos. O imperativo do trabalho, no mosteiro, no caso das comunidades femininas, implicava que as mulheres se entregassem às tarefas atribuídas socialmente ao seu género ${ }^{27}$ : a costura, os bordados e, sobretudo, a cozinha, mesmo que entre estas houvesse uma divisão de acordo com o estatuto social das consagradas. Por essa via, o labor feminino cumpria um imperativo vocacional coerente não só com a expectativa do sexo que o desempenhava, como também permitia exprimir, através de uma obra- produto, uma devoção cujas caraterísticas estão profundamente implicadas com as restantes memórias, cultura e vivências do mosteiro. Assim, os temas do sagrado, os referentes evocados nas meditações, nas leituras, nas orações, na escuta da liturgia constituem motivos de uma mundividência que se exterioriza enquanto objeto comunicativo nos objetos que elas produzem e criam, e em que elas interpretam o seu mundo, comunicando-o, idealizando-o, projetando nesses bens um mundo reflexivo feito de vivências interiores de uma linguagem e de um espaço sagrados.

Para aprofundarmos essa hipótese que deixamos colocada, era necessário debruçarmo-nos sobre o estudo do quotidiano real dessas casas monásticas, de difícil acesso, porque não se pode observar um espaço e uma tradição que já desapareceram. Mas hoje, quando visitamos estes lugares, alguns restaurados e convertidos em museus, em espaços de um turismo cultural e religioso, o que vemos? Do que nos falam os retábulos, as pinturas, os azulejos, as alfaias sagradas e os panejamentos, o mobiliário, os livros e os títulos que ornamentam as bibliotecas? Há toda a criação de uma ambiência visual, auditiva, intelectiva, evocadoras do sagrado e das narrativas do sagrado cristão que imaginamos terem cercado quem imergiu naqueles espaços conclusos. Com isso não queremos dizer ou desvalorizar os documentos históricos,

${ }^{27}$ Consiglieri 1999: 57-73, um muito breve apanhado sobre a tradição monástica enquanto continuum histórico e a vida conventual quotidiana dos mosteiros femininos portugueses. Oliveira 2013: 75. 
os testemunhos e os estudos que atestam, em particular para determinadas épocas, uma piedade oscilante ou a presença do profano e do mundano dentro de um espaço que, em teoria, devia rejeitá-lo. Mas, dentro do tema a que nos propusemos, parece-nos que omitir essa parte tão importante e tão fundamental das vivências e das experiências e das linguagens proporcionadas pelo claustro religioso na fundamentação da doçaria conventual como uma obra-produto criada pela mesma cultura e pelos mesmos agentes corre o risco de gerar uma leitura parcial e mesmo superficial desse fenómeno.

Não conseguimos, de facto, ter mais do que um vislumbre do que seria a vivência do quotidiano desses espaços conclusos. Mas conseguimos ter acesso à cultura religiosa, literária e ritualística, dominante nesses espaços, lida, ouvida, cantada, meditada, não só nas liturgias como também na solidão da cela, seja em primeiro lugar os textos bíblicos, sejam as obras dos Padres da Igreja ou dos fundadores dos movimentos. Dentro desse corpus vastíssimo, encontram-se discursos e mensagens que legitimam, no nosso entender, o sabor doce e o prazer gustativo enquanto estratégias de aproximação mística a uma realidade espiritual. Ou seja, a comunicação e a cultura religiosas exprimem-se dentro de uma metafórica que pode contaminar ou contagiar o saber fazer dessas mulheres.

Neste sentido, concentremo-nos apenas no texto sagrado por excelência, com que toda a literatura patrística e espiritual ocidental dialoga, a Bíblia. As metáforas alimentares pontilham o discurso, cumprindo funções comunicativas, exegéticas e mesmo exortativas. Particularmente significativo como eixo de sentido, encontrámos o binómio carência alimentar e saciedade, ou entre fome e a abundância: estar feliz e com Deus é uma condição efetiva de conforto alimentar ou comparável a um estado de abundância de recursos; estar triste e privado de Deus é, pelo contrário, expresso como uma privação alimentar e a uma ausência de recursos ${ }^{28}$. Mas avançaremos um pouco mais: não está só em causa a saciedade, ou a ausência de fome como condição biológica para a preservação da vida, mas sim a apetência superlativa por um determinado sabor que está para além da fome. Pode haver saciedade, evidentemente, mas, e quando a suprema felicidade do encontro com Deus se exprime para além da quantidade dos alimentos que debelam a fome e se encaixam na qualidade, na especificidade de determinados alimentos que proporcionam o estar "deliciado"?

A plenitude do encontro, da integração com Deus, explora, frequentemente, a metáfora do doce, do leite, do mel, dos frutos acessíveis. Esse encontro pode ter uma expressão espacial, de retorno, ou chegada, a uma terra prometida (Ex. 33, 3 Deus dirige-se a Moisés prometendo-lhe a entrada numa terra

${ }^{28}$ Desenvolvemos este tema em Dias 2008: 157-175. 
de delícias: Vade, ascende de loco isto tu, et populus tuus quem eduxisti de terra Aegypti [...] et intres in terram fluentem lacte et melle ${ }^{29}$ (também em Ex. 3, 7 e em Dn. 26, 9)); a um paraíso, (cf. Gen. 2, 9 Produxit Dominus Deus de humo omne lignum pulchrum uisu, et ad uescendum suaue; Jr. 2, 7 Introduxi uos in terram Carmeli ut comederetis fructum eius et bona illius30); ou a um destino escatológico (Jo. 22, 2: medio plateae eius, et ex utraque parte fluminis lignum uitae, afferens fructus duodecim, per menses singulos, reddens fructum suum, et folia ligni ad sanitatem gentium $\left.{ }^{31}\right)$.

A esse conceito se associa ainda a mensagem de que há um alimento adequado para o progresso de seres imaturos, crianças na fé, particularmente explorado no NT. Na 1Cor 3, 1-2, Paulo explicita o seu modo de comunicar a fé: Et ego, fratres, non potui uobis loqui quasi spiritualibus, sed quasi carnalibus. Tanquam paruulis in Christo, lac uobis potum dedi, non escam... ${ }^{32}$. Também na IPet. 2, 2, sicut modo geniti infantes, rationabile, sine dolo lac concupiscite: ut in eo crescatis in salutem: si tamen gustastis quoniam dulcis est Dominus ${ }^{33}$. Assim, tal como o maná para o povo no deserto, há, do ponto de vista do caminho espiritual, um estádio semelhante ao da infância, ao da imaturidade, em que simbolicamente o homem se deve alimentar dos alimentos "fáceis", "gratuitos" e "doces".

Restringimo-nos a poucos exemplos em que é nítida esta identificação entre o estado de graça da presença de Deus e as sensações visual da beleza e a gustativa do doce e do prazer alimentar. Um tem a ver com a eucaristia e a instituição das devoções eucarísticas sob a forma da contemplação e da adoração ao Santíssimo Sacramento, o Lausperene e a festa do Corpus Christi, ou seja, as solenidades do Corpo de Deus enquanto expressões ritualísticas. Significativamente, o salmo 33, 9 preenche os dois sentidos, o do gozo visual e do gozo gustativo: gustate et uidete quoniam Dominus suauis est $t^{34}$. Muito evocado

${ }^{29}$ Ex. 33, 3: "Vai, parte daqui com o povo que fizeste subir do Egipto [...] Ide para essa terra onde corre leite e mel”. Servimo-nos de Colunga-Turrado (1994) Biblia Vulgata, Biblioteca de Autores Cristianos, Madrid, (1. ed. 1946). As traduções em português seguem a edição da Bíblia Sagrada, (Alves, Herculano coord.) Difusora Bíblica, 5? ed., 3ª reimp., 2012.

${ }^{30}$ Gen. 2, 9: "o Senhor fez desabrochar da terra toda a espécie de árvores agradáveis à vista e de saborosos frutos para comer"; Jr. 2, 7: "fiz-vos entrar na terra do Carmelo para que comeis o seu fruto e as suas delícias".

31 Jo. 22, 2: "no meio da praça da cidade e nas margens do rio está a árvore da vida que produz doze colheitas de frutos; em cada mês o seu fruto, e as folhas da árvore servem de medicamento para as nações".

32 1Cor 3, 1-2: "Quanto a mim, irmãos, não pude falar-vos como a homens espirituais, mas como a homens carnais, como a criancinhas em Cristo. Foi leite que vos dei a beber, e não alimento sólido $[\ldots]$ ”.

33 I Pet. 2, 2. A tradução latina assegura uma precisão de sentido que o Português torna menos percetível: "como crianças recém-nascidas, ansiai pelo leite espiritual, não adulterado, para que ele vos faça crescer para a salvação, se é que já saboreastes como o Senhor é bom”. O termo latino empregue é dulcis, ou seja, "doce".

34 S1. 33, 9: "Saboreai e vede como o Senhor é bom". 
e parafraseado ainda hoje nos cânticos que acompanham a comunhão nas missas dominicais, e por todos reconhecido, merece ser lido na versão latina da Vulgata, tal como seria lido e meditado nos ambientes monásticos do séc. XVII, uma vez que a tradução portuguesa pede que saboreemos e vejamos como o Senhor é genericamente "bom" (belo?; saboroso?; bondoso?), ao passo que a versão latina pede que saboreemos e vejamos como o Senhor é "doce"35. Sendo um texto do AT, ele anuncia e justifica a eucaristia como ritual de tornar presente Deus entre os homens através do corpo e do sangue do Seu filho, e assim seria integrado como uma referência tipológica para a instituição da eucaristia por Jesus Cristo, já nos Evangelhos, abrindo a porta para uma leitura sensitiva da comunhão eucarística e da contemplação da espécie eucarística perfeitamente integrada nas práticas cristãs. A vinda de Cristo proporcionou aos homens algo que até então lhes esteve vedado, que foi a proximidade sensitiva, sobretudo visual, com Deus. O Deus Pai do AT faz-se ouvir às vezes, mas não se deixa ver ${ }^{36}$. Já o Deus Filho, Jesus Cristo, apresentou uma existência terrena, pode ser ouvido, visto, tocado... saboreado, que foi a última graça neste deixar-se aproximar pelos homens, que são convidados a, por um grande mistério, conservar a presença do Senhor, degustando-o. Na noite da última Ceia em que se instituiu o ritual eucarístico, a transformação do vinho e do pão no Seu corpo e sangue veio, por um lado, abrir a porta para o ciclo sacrificial da morte do seu corpo, que aconteceria no dia seguinte, mas, por outro, garantir uma permanência concreta, em espécie, de Deus entre os homens para além da vida terrena do seu filho. Essa

${ }^{35}$ Ressonâncias desse verso no NT em Heb. 6, 5, gustauerunt nibilominus bonum Dei uerbum, uirtutesque saeculi uenturi, "provaram a boa palavra de Deus e as maravilhas do futuro"e em Lc. 1, 53, no Magnificat proferido por Maria já grávida na visita a sua prima Isabel “Dominus [...] Exurientes impleuit bonis "O Senhor [...] aos famintos encheu de bens".

${ }^{36}$ Para nos mantermos dentro do mesmo registo literário da salmodia poética, cf. S1. 4 Salmo 4 “[...] Levantai sobre nós, Senhor, a luz da Vossa face!/ Derramastes no meu coração mais alegria/ Do que quando abundam para eles o trigo e o vinho./ Deito-me em paz e logo adormeço [...]"; S1. 10 "[...] Depois, diz no seu coração: “-Deus esqueceu-se, oculta o seu rosto, nada vê"; S1. 13 "Até quando, Senhor, me esquecereis tão duramente?/ Até quando me escondereis a Vossa face"; S1. 27 "O meu coração pressente os teus dizeres: '-Procurai a minha face'!/É a tua face, Senhor, que eu procuro;/ Não escondais de mim o Vosso rosto [...]”; o muito conhecido S1 42 "Assim como a corça suspira pelas correntes da água/ Assim também minha alma/ Suspira por Vós, meu Deus./ A minha alma tem sede do Senhor,/ Do Deus vivo./ Quando poderei eu chegar,/ Para contemplar a face de Deus?/ As minhas lágrimas são para mim o meu pão/ Durante todo o dia e toda a noite me dizem:/ 'onde está o teu Deus?"'. No plano narrativo, Moisés, com quem Deus falava, anseia por ver a face de Deus e veja-se a dramática resposta: Ex. 33, 18-23 "Moisés disse: 'Mostrai-me a Vossa glória'. E Deus respondeu: '-Farei passar diante de ti toda a Minha bondade, e proclamarei diante de ti o nome de Javé. [...] Mas não poderás ver a minha face, pois o homem não pode contemplar-Me e continuar a viver'. O Senhor disse: Está aqui um lugar próximo de Mim; conservar-te-ás sobre o rochedo. Quando a minha glória passar, colocar-te-ei na cavidade do rochedo, e cobrir-te-ei com a Minha mão até que Eu tenha passado. Retirarei a mão, e poderás então ver-Me por detrás. Quanto à Minha face, ela não pode ser vista'.” 
permanência concreta de Deus entre os homens, ininterrupta sempre que se celebra, deixa-se saborear e ver, como diz o salmo. Deixa-se saborear e entender, portanto. Dessa integração de Deus no corpo de quem comunga, resulta uma experiência boa, de prazer e felicidade, porque, parafraseando o mesmo Salmo, não passa fome o homem que Nele se abriga. A felicidade suprema para um cristão oferece-se, pois, na comunhão, que, no seu plano concreto, resulta da ingestão do bem que é o Deus que se dá. Independentemente da crença individual, ou das práticas mais ou menos religiosas, mais ou menos intelectualizadas, pensamos ser inegável que o momento alto da vivência cristã se faz, desde há séculos, numa experiência de sabor.

O segundo exemplo é o Cântico dos Cânticos, um dos livros do Antigo Testamento ${ }^{37}$. Esse livro constitui um conjunto de vozes na primeira pessoa, em que um par amoroso, um noivo e uma noiva exprimem o seu amor e a sua busca do outro, num cenário que oscila entre o interior e o exterior; entre a pompa de um palácio e a simplicidade das tendas; entre um cortejo áulico e jardins e os mais comuns campos agrícolas, pomares, vinhas, pastos. A essa efusão lírica do amor sentido assistem personagens secundárias, os companheiros do noivo e da noiva, o que carrega de um pendor também dramático um texto eminentemente lírico. As exegeses judaicas e cristãs, quanto ao caráter sagrado desse texto, não coincidem entre si, mas tocam um ponto comum: o erotismo, o amor carnal que aí se celebra funciona como uma alegoria para um amor espiritual mais alto, entre o fiel ou as comunidades de fiéis e Deus, descrevendo e caraterizando essa relação como fonte de graças, de gozo sensual e de felicidade.

Ou seja, a linguagem dos sentidos humanos é a única que pode ser verbalizada ou materializada para o entendimento humano, num estado impreparado ou imaturo para o transcendente. Convocamos as palavras de Gregório Magno para a demonstração da legitimidade do emprego das sensações e da linguagem do amor humano como mediadores da caminhada mística:

Assim é que, neste livro intitulado Cântico dos Cânticos se empregam termos de um amor que parece carnal: para que a alma, despertada da sua sonolência, se aqueça pelo estímulo dos convites que lhe são familiares e, graças à linguagem do amor deste mundo, seja estimulada para o amor do Alto. Neste livro mencionam-se os vocábulos de beijos (oscula) de seios (ubera), de joelhos (genae, de coxas (femora). [...] quando são referidas estas partes do corpo e se convida ao amor, deve-se atender ao modo maravilhoso e misericordioso de Deus agir sobre nós, Ele que, para incendiar o nosso coração e gerar o amor sagrado, recorre à linguagem do nosso amor profano ${ }^{38}$.

37 Gaspar, 2012.

38 No séc. VI, o papa Gregório Magno, Comentário ao Cântico dos Cânticos, 3 (tradução própria), acerca da comunicação alegórica, "por enigmas" que é usada no discurso divino, de modo a fazer-se entender e escutar por um homem insensível ao entendimento exclusivamente 


\section{Conclusão}

Em breves palavras de conclusão, pensamos ter traçado algumas hipóteses e ter sustentado alguns argumentos para a legitimidade da associação entre a religião e o doce materializada na doçaria tradicional, em particular nas suas manifestações conventuais, em que este é portador de uma comunicação entre os homens e dos homens com o sagrado, sob a forma de cumprimento de um ritual cujo entendimento, hoje, as práticas sociais de consumos dos doces, seja da doçaria popular ou seja da doçaria conventual, podem obnubilar.

Em termos de demonstração, servimo-nos da linguagem religiosa primeira, aquela que alimenta a liturgia e as práticas memorialísticas e rituais das vivências religiosas, visíveis até hoje nos ambientes religiosos praticantes, não exclusivamente monásticos: a Bíblia, as narrativas sagradas, os salmos. Apresentam esses textos, destinados a transmitir um caminho do religioso entre os homens, formas de validação metafórica e real do sabor doce, para além dos fatores contextuais designados no início do artigo. Outros o fazem com igual coerência, e somente não os analisamos por necessidade de síntese: pertencem, neste caso, aos próprios testemunhos dos homens e mulheres espirituais que viveram a experiência do claustro, ou formas de vida consagrada, produzindo uma literatura mística e espiritual muito arredada do nosso consumo académico.

Mas terminamos, como começámos, com a evocação de uma obra de arte não literária, visual, próxima dos nossos tempos, que acreditamos exprimir bem a justeza da associação universal entre o doce e o sagrado: recentemente restaurada e exibida, essa obra cruza e unifica os complexos sentidos do que aqui expusemos: o doce, conventual ou popular, como veículo de comunicação de prazer gustativo e de prazer visual enquanto manifestação do sagrado entre os homens. Falamos do Arcano Místico da Ribeira Grande, da Ilha de S. Miguel, Açores, obra recentemente considerada pelo Governo Regional dos Açores como Tesouro Regional. Em 1833, a Madre Margarida do Apocalipse, freira do antigo Mosteiro do Santo Nome de Jesus, foi expulsa do Mosteiro em consequência da extinção das ordens religiosas. Essa madre não parece ter sentido as alegrias do termo da sua reclusão, pelo contrário. Tendo-lhe sido retirado o seu espaço de conforto espiritual, dedicou o resto da sua vida a esculpir um conjunto escultórico de mais de noventa figuras, alusivas a episódios do Antigo e do Novo Testamento, pequenas figuras

espiritual: "Depois que o homem foi expulso das alegrias do paraíso, entrando no exílio da vida presente, tem o coração enceguecido ao entendimento espiritual. Se a voz divina dissesse a este coração cego: 'Vem a mim' ou 'Ama a Deus' como foi dito na Lei (AT) esta, exilada, rígida de insensibilidade pelo torpor, não entenderia o que foi dito. Assim, é por enigmas que o discurso divino se dirige à alma sonolenta do frio e que, a partir das realidades que conhece bem, lhe inspira secretamente um amor que não conhece". 
polícromas, tendo até $20 \mathrm{~cm}$ cada uma, agora dispostas num grande móvel expositor, todas identificadas com legendas. O material usado na elaboração das figuras foi farinha de arroz e de trigo, goma-arábica, gelatina animal e vidro moído como ligantes e como decoração. Em suma, a matéria-prima que uma mulher tinha à mão.

Retirada do seu ambiente e extinto o mundo em que fora criada, a Madre Margarida do Apocalipse continuou a comunicar e a narrar o mundo que the dava sentido a si mesma, compondo uma obra de arte em que associa a maravilha visual e os ingredientes da cozinha, materiais bem conhecidos e familiares das mulheres. Trata-se de um caso individual, mas quer-me parecer que essa freira açoriana, de quem pouco se sabe, não seria a única mulher que, servindo-se das artes e dos meios a que tinha acesso, participa e comunica a vivência espiritual de uma realidade distante da maioria de nós, que consumimos os doces desenquadrados do sistema comunicativo religioso que os motivou.

\section{REFERENCIAS}

Braga, I. (2004), Arte Curiosa Para Conserveiros e Copeiros, Colares Editora, Sintra, Portugal.

Camino, F. (2002), Barroco, Ollero y Ramos Editores SL, Madrid.

Catroga, F. (1988), "Laicismo e a questão religiosa em Portugal (1865-1911)", Análise Social, 24: 211-273.

Chevalier, A. (1982), Dicionário dos Simbolos, Teorema, 497.

Consiglieri, C. (1999), A Tradição Conventual na Doçaria de Lisboa, Colares Editora, Sintra, Portugal.

Dalby, A. (2002), Dangerous Tastes, a History of Spices, Ashgate.

Davidson, A. (2006), The Oxford Companion to Food, Oxford University Press.

Dias, P.(2015), “A Grande Refeição: metáforas alimentares na descrição do transcendente religioso na Cultura Ocidental" in Soares C., Ribeiro C. (2015), Odisseia de Sabores da Lusofonia, IUC, Champagnat, Coimbra, Curitiba.

Dias, P. (2008), “A Linguagem dos Alimentos nos Textos Bíblicos. Sentidos para a Fome e Para a Abundância", Humanitas 60: 157-175.

D’Ors, E. (2002), Lo barroco, (1935, 1. a ed.), Tecnos/Alianza, Madrid.

Gaspar, R. (2012), A Festa dos Sentidos. O tema dos Esponsais a partir do Cântico dos Cânticos. Universidade de Coimbra (Tese de Mestrado).

Goldstein, D. (2015), The Oxford Companion of Sugar and Sweets, Oxford-New York.

Grégoire le Grand (2007), Commentaire sur le Cantique des Cantiques (Bélanger R. ed.), SC 314, Le Cerf Paris.

Hills, H. (ed.) (2011), Rethinking the Baroque, Ashgate.

Kiple, K., Ornelas, K. (eds.) (2000), The Cambridge World History offood, 2 vols, Cambridge 
University Press.

Luard, E. (2001), Sacred Food, Chicago Review Press, 242-250.

Maravall, J. A. (1998), La Cultura del Barroco Análisis de una estructura histórica, (1975, 1. ${ }^{\text {a }}$ ed.), Ariel Editorial, Madrid.

Moskowitz, H. (1971), "The Sweetness and Pleasantness of Sugars", The American Journal of Psychology 84: 387-405.

Oliveira, C. (2013), O Pão Nosso de cada Dia. Alimentação no Monaquismo Beneditino, Universidade de Coimbra (Tese de Mestrado), 75.

Pessanha, S. (1957), Doçaria Popular Portuguesa, (reed. Ferreira V., 1997), Colares Editora, Sintra, Portugal.

Ribeiro, E. (1997), O Doce nunca Amargou. Doçaria Portuguesa. História. Decoração. Receituário, Colares Editora, Sintra, Portugal.

Saramago, A. (2000), Doçaria conventual do Alentejo, As receitas e seu enquadramento histórico, Colares Editora, Sintra, Portugal, 16.

Sousa, D. (2011), A Doçaria Conventual Portuguesa, Colares Editora, Sintra, Portugal.

Sousa, D. Ferreira, (2013), Arte Doceira de Coimbra: conventos e tradições, Colares Editora, Sintra, Portugal.

Tavares, P. (1999), Mesas, Doces e Amores no séc. XVII Português, Colares Editora, Sintra, Portugal. 